\title{
Development and performance evaluation of single row manual seed planter
}

\author{
Ochin N. G. • Adewumi A. A. • Faleye T.`• Adeyi A. M. • Willoughby F. A. $\bullet$ Ehiosun P.
}

National Centre for Agricultural Mechanization (NCAM), P.M.B. 1525, Ilorin, Kwara State, Nigeria.

*Corresponding author. E-mail: topeleye999@gmail.com

Accepted $13^{\text {th }}$ March, 2019.

\begin{abstract}
Planting of seed crops for cash and consumption by the Nigeria farmers is largely done manually using human labour. This is tedious and time consuming, therefore, the need to mechanize planting has led to various researches in the development of seed planters of various capacity. A single row manual seed planter was developed by NCAM to plant maize, cowpea and guinea-corn. The number of seeds per hole depends on the designed seed metering plate for each of the crop. Planting space was $24 \times 60 \mathrm{~cm}$, the total area of land used for field operation was $0.09 \mathrm{ha}$ and moisture content of the soil was $8.01 \%$. The average values for effective field capacity, theoretical field capacity, field efficiency and the total time for maize, cowpea and guinea-corn during field test are $0.1186,0.1205,0.1108 \mathrm{ha} / \mathrm{hr}$; $0.1215,0.1231,0.1198 \mathrm{ha} / \mathrm{hr} ; 97.14,97.91,97.54 \%$ and $0.76,0.75,0.77 \mathrm{hr}$ respectively. From this research work, it was observed that there was significant difference $(0.007$ to 0.031 at $P \leq 0.05)$ in effective and theoretical field capacity of the machine for maize, cowpea and guinea-corn but no significant difference in field efficiency of the machine for the three crops. Therefore, performance of the machine was satisfactory when compared to manual planters developed by other researchers and the traditional method of planting. Development of this planter has reduced the challenges associated with the traditional method of planting using peasant tools and enhanced planting seed crops to increase food security in Nigeria.
\end{abstract}

Keywords: Planter, seeds, single row, performance evaluation.

\section{INTRODUCTION}

Agriculture is one of the major promising areas for rapid growth and development of Nigeria economy through the use of indigenous agricultural machinery that is readily available and affordable to farmers in Nigeria.

Over the years, researchers have been developing different kinds of planters, each design having its own working principle which is aimed at addressing the issue of planting system in Nigeria. Among the developed planter is the hand operated seed planter otherwise known as Jab planter, the electrostatic planter. The need to solve challenges associated with each planter leads to the development of new planters; the jab planter for an example performed to its capacity, but has the problem of pressing the handle while planting, this resulted to inconsistent spacing which called for an improved planter to increase the output in a shorter time.

Kyada (2014) developed a manual seed planter and made the operation, adjustment and maintenance principles of the planter simple for effective handling by unskilled farmers. Thorat et al. (2017) designed and fabricated seed sowing machine. In his design, planting depth, row spacing, seed dropping etc. were considered to ease the sowing operation with little effort.

The common edible foods planted and eaten in Nigeria include:-cowpeas, soybeans, maize, groundnut, okra, cotton, kenaf, sorghum, etc. They are planted by placing 
and covering it in the soil at definite distance apart and definite depth or by broadcasting which is accomplished mechanically or manually (Kepner et al., 2005).

Under different tillage system, spacing uniformity, timing, rate of emergence and plant population in corn (maize) stand are the most common characteristics used by producers in evaluation of planter performance (Liu et al., 2005; Conley et al., 2005). Uneven plant density decreased grain yield when compared to uniform stand treatments. Alba - Hurst farms (2004) once reported that plant spacing uniformity and rate of emergence were affected by planter speed.

The recommended seed spacing and depth of seed placement vary from crop to crop and different Agroclimatic conditions to achieve optimum yield. The expected seed spacing and depth for planting maize is 30 $\mathrm{cm}$ and $2.5 \mathrm{~cm}$ respectively, for guinea corn is $60 \mathrm{~cm}$ and for rice is $30 \mathrm{~cm}$, (Adisa, 2011). However, in this research work a single row manual seed planter was developed and evaluated to overcome the challenges in seed crop planting and improve food security in Nigeria.

\section{MATERIALS AND METHODS}

\section{Description of the machine}

The manually operated single row seed planter consists of two handles, seed hopper, furrow opener, ground wheels, furrow covering device, seed metering device, wheel press, chain, sprocket and a support stand. During design stage, more attention was given to the metering device to avoid any damage to the physical properties such as length, width, thickness, density, and roundness of the crop seeds that could happen during planting operation. The same consideration was given by (Ndirika and Oyeleke, 2006; Mohammed, 2002) during the design and fabrication of the seed planter. However, the manual seed planter was set in motion by the operator pushing it from behind. As the operator pushed the machine forward, the ground wheel rotates and drives the seed metering device through the connection of chain and sprocket to drop seed into the soil opened by the furrow opener and covers the seed with soil by furrow coverer. The speed of operator determines the speed of the manual seed planter. Therefore, operator moved in a steady motion to avoid missing hills.

\section{Design considerations}

The following factors were considered in the design of the planter:

1. The physical properties of the agricultural material such as length, width, thickness etc. which varies in shape, density and size.

2. The ease of fabrication of component parts.
3. The safety of the operator

4. Resistivity of metering device to corrosion

5 . The operation of the machine shall be simple for small scale or rural farmers.

6. Availability of the component parts at the local market.

\section{Performance test}

\section{Laboratory test}

A test was conducted in the laboratory to examine the performance of the metering mechanism and to make any adjustment or modification required by machine before subjecting it to field test. Proper adjustment was made to avoid mechanical damage of the seeds by the metering device. Also it was observed that the seed dropping varies with respect to seed size.

\section{Field test}

The total area of the field used for testing was 0.09 ha $\left(900 \mathrm{~m}^{2}\right)$ and the type of soil used was sandy-loam with $8.01 \%$ moisture. The land preparation (ploughing and harrowing) was properly done to provide easy penetration of the tender root into soil to get adequate nutrients required for proper growth and development. The variety of seeds used were dent corn TZB (FARZ-23), cowpea IT89KD-391 and guinea corn. The intra and inter row spacing was $24 \times 60 \mathrm{~cm}$ (Table 1). Though this is varied depending on the type of seed and agro-ecological zone of each region. The planting depth was not too deep for quick and proper germination and not too shallow to prevent rodent attack on the planted seed. The percentage of plant emergence, size of the grain was calculated using Mabayoje and Verma (1994) and Mohsenin (1970) equation.

Percentage of plant emergence $=\frac{\text { Average percentage of plant emergence per row }}{\text { Averageof total seed dropped }} \times 100 \ldots . . . .1$

$D_{a}=\frac{L+W+T}{3} \ldots \ldots \ldots \ldots \ldots \ldots \ldots$

where,

$D_{\mathrm{a}}=$ arithmetic diameter of seed

$\mathrm{L}=$ length of seed

$\mathrm{W}=$ width of seed

$\mathrm{T}=$ thickness of seed

\section{RESULTS AND DISCUSSION}

Table 1 shows the basic specification such as planting depth, planting space, number of seeds drop per hole, 
Table 1. The specification of the manual seed planter.

\begin{tabular}{ll}
\hline Parameters & Specifications \\
\hline Average row spacing & $24 \mathrm{~cm}$ \\
Number of seeds per hole for maize & $1-2$ \\
Number of seeds per hole Cowpea & 1 \\
Number of seeds per hole Guinea-corn & $7-8$ \\
Number of rows & 1 \\
Planting space & $24 \times 60 \mathrm{~cm}$ \\
Planting depth & $6 \mathrm{~cm}$ \\
Power source & Ground wheel \\
Type of metering system & Horizontal plate type \\
Area of field & $900 \mathrm{~m}^{2}$ \\
Type of soil & Sand loamy \\
Soil moisture content & $8.01 \%$ \\
Effective field capacity for maize, cowpea and guinea-corn & $0.1186,0.1205$ and $0.1168 \mathrm{ha} / \mathrm{h}$ \\
\hline
\end{tabular}

Table 2. Number of seeds dropping.

\begin{tabular}{|c|c|c|c|c|c|}
\hline Seed crop & $\begin{array}{c}\text { Seed size } \\
(\mathrm{mm})\end{array}$ & $\begin{array}{c}\text { No. of dropping in } 1^{\text {st }} \\
\text { stroke }\end{array}$ & $\begin{array}{c}\text { No. of dropping in } 2^{\text {nd }} \\
\text { stroke }\end{array}$ & $\begin{array}{l}\text { No. of dropping in } \\
3^{\text {rd }} \text { stroke }\end{array}$ & $\begin{array}{c}\text { Average no. of } \\
\text { stroke }\end{array}$ \\
\hline & 8.67 & 1 & 2 & 2 & 2 \\
\hline \multirow[t]{3}{*}{ Maize } & 8.69 & 1 & 2 & 2 & 2 \\
\hline & 8.55 & 1 & 2 & 1 & 1 \\
\hline & 3.75 & 8 & 8 & 7 & 8 \\
\hline \multirow[t]{3}{*}{ Guinea-corn } & 3.67 & 7 & 8 & 8 & 7 \\
\hline & 3.46 & 6 & 7 & 8 & 8 \\
\hline & 7.67 & 2 & 2 & 1 & 2 \\
\hline \multirow[t]{2}{*}{ Cowpea } & 7.56 & 1 & 1 & 2 & 1 \\
\hline & 7.55 & 1 & 1 & 1 & 1 \\
\hline
\end{tabular}

moisture content of soil, type soil used, horizontal metering device and effective field capacity of the developed manual seed planter. These are very important in determining the effectiveness and efficient of the seed planter and any other related machine.

Table 2 shows the size of maize, cowpea, and guineacorn, in every complete revolution of planter wheel there is number of seeds drop through a designed seed plate relative to the size of each of the seed crop.

Table 3 shows the results for the performance evaluation of manual seed planter for maize, cowpea and guinea-corn. The effective field capacity, theoretical field capacity and efficiency of the machine for maize, cowpea and guinea-corn are $0.1186,0.1205,0.1168 \mathrm{~kg} / \mathrm{h}$; $0.1215,0.1231,0.1198 \mathrm{~kg} / \mathrm{h} ; 97.61,97.91$ and $97.54 \%$ respectively. This planter performed satisfactorily when compare to field efficiency of $76.5 \%$ obtained by Rabbani et al. (2016) and planting capacity of $0.0486 \mathrm{ha} / \mathrm{hr}$ obtained by lbukun et al. (2014) during performance evaluation of manual maize planter.
Table 4 shows the percentage of plant emergence. The variation in number of dropping was due to non-uniformity and size of seed which resulted in the number of plant emergence. Also, the figure 1 shows the percentage of plant emergence for the crops and maize has the highest percentage. The higher the number of seeds dropped the more the plant emergence.

Table 5 shows the statistical analysis of result obtained using ANOVA. It was observed that there was significant different in effective field capacity and theoretical field capacity for maize, cowpea and guinea-corn but there was no significant different in field efficiency of the machine for the three crops. It means the three varieties of the crop seeds are suitable for the planter.

\section{CONCLUSION}

Manual seed planter was developed and its performance evaluation was done satisfactory. There was significant 
Table 3. The results for the performance evaluation of manual seed planter used for planting maize, cowpea and guinea-corn.

\begin{tabular}{|c|c|c|c|c|c|c|c|c|}
\hline Crops & & $\begin{array}{c}\text { Productive } \\
\text { time (s) }\end{array}$ & $\begin{array}{l}\text { Turning } \\
\text { time (s) }\end{array}$ & $\begin{array}{c}\text { Unproductive } \\
\text { time (s) }\end{array}$ & $\begin{array}{c}\text { Total } \\
\text { time (s) }\end{array}$ & $\begin{array}{l}\text { Effective field } \\
\text { capacity (ha/h) }\end{array}$ & $\begin{array}{l}\text { Theoretical field } \\
\text { capacity (ha/h) }\end{array}$ & $\begin{array}{c}\text { Field } \\
\text { efficiency }(\%)\end{array}$ \\
\hline \multirow{3}{*}{ Maize } & 1 & 2666 & 63 & 6 & 2735 & 0.1184 & 0.1215 & 97.44 \\
\hline & 2 & 2656 & 55 & 5 & 2716 & 0.1192 & 0.1219 & 97.78 \\
\hline & 3 & 2675 & 59 & 6 & 2740 & 0.1182 & 0.1211 & 97.60 \\
\hline \multirow[t]{2}{*}{ Average } & & 2635 & 59 & 5.7 & 2730 & 0.1186 & 0.1215 & 97.61 \\
\hline & 1 & 2600 & 60 & 4 & 2640 & 0.1227 & 0.1246 & 98.47 \\
\hline \multirow[t]{2}{*}{ Cowpea } & 2 & 2645 & 58 & 6 & 2709 & 0.1196 & 0.1224 & 97.71 \\
\hline & 3 & 2650 & 61 & 5 & 2716 & 0.1192 & 0.1222 & 97.54 \\
\hline \multicolumn{2}{|l|}{ Average } & 2632 & 60 & 5 & 2688 & 0.1205 & 0.1231 & 97.91 \\
\hline \multirow{3}{*}{$\begin{array}{l}\text { Guinea- } \\
\text { corn }\end{array}$} & 1 & 2700 & 65 & 8 & 2773 & 0.1168 & 0.1200 & 97.33 \\
\hline & 2 & 2710 & 60 & 7 & 2777 & 0.1166 & 0.1196 & 97.57 \\
\hline & 3 & 2705 & 58 & 6 & 2769 & 0.1170 & 0.1197 & 97.74 \\
\hline Average & & 2705 & 61 & 7 & 2773 & 0.1168 & 0.1198 & 97.54 \\
\hline
\end{tabular}

The total area of field $=0.09$ ha $\left(900 \mathrm{~m}^{2}\right)$

Table 4. Percentage of plant emergence.

\begin{tabular}{lcccc}
\hline Variety of seed & $\begin{array}{c}\text { Planting } \\
\text { population/row }\end{array}$ & $\begin{array}{c}\text { Height of germinated } \\
\text { seed (cm) }\end{array}$ & $\begin{array}{c}\text { Average number of } \\
\text { seeds drop }\end{array}$ & Plant emergence (\%) \\
\hline \multirow{3}{*}{ Maize } & 12 & 11 & 12 & 100 \\
Average & 11 & 9 & 12 & 91.67 \\
& 10 & 7 & 12 & 83.33 \\
Cowpea & 11 & 9 & 12 & 91.67 \\
& & & & \\
Average & 8 & 6 & 9 & 88.89 \\
& 7 & 7 & 9 & 77.78 \\
Guinea-corn & 9 & 8 & 9 & 100 \\
Average & 8 & 7 & 9 & 88.89 \\
& 42 & 10 & & 80.77 \\
& 49 & 9 & 52 & 94.23 \\
\end{tabular}

Table 5. ANOVA results for the performance evaluation of manual seed planter used for planting maize, cowpea and guinea-corn @ $\mathrm{P} \leq 0.05(5 \%)$.

\begin{tabular}{|c|c|c|c|c|c|c|}
\hline & & Sum of Squares & df & Mean Square & $\mathbf{F}$ & Sig. \\
\hline \multirow{3}{*}{ Productive time (s) } & Treatment (Crop type) & 8080.889 & 2 & 4040.444 & 13.874 & 0.006 \\
\hline & Error & 1747.333 & 6 & 291.222 & & \\
\hline & Total & 9828.222 & 8 & & & \\
\hline \multirow{3}{*}{ Turning time } & Treatment (Crop type) & 6.222 & 2 & 3.111 & 0.298 & 0.753 \\
\hline & Error & 62.667 & 6 & 10.444 & & \\
\hline & Total & 68.889 & 8 & & & \\
\hline \multirow{2}{*}{ Unproductive time (s) } & Treatment (Crop type) & 6.222 & 2 & 3.111 & 4.000 & 0.079 \\
\hline & Error & 4.667 & 6 & 0.778 & & \\
\hline
\end{tabular}


Table 5. Contd.

\begin{tabular}{|c|c|c|c|c|c|c|}
\hline & Total & 10.889 & 8 & & & \\
\hline \multirow{3}{*}{ Total time } & Treatment (Crop type) & 154426192.889 & 2 & 77213096.444 & 1.116 & 0.387 \\
\hline & Error & 415273894.667 & 6 & 69212315.778 & & \\
\hline & Total & 569700087.556 & 8 & & & \\
\hline \multirow{3}{*}{ Effective field capacity (ha/h) } & Treatment (Crop type) & 0.000 & 2 & 0.000 & 6.500 & 0.031 \\
\hline & Error & 0.000 & 6 & 0.000 & & \\
\hline & Total & 0.000 & 8 & & & \\
\hline \multirow{3}{*}{ Theoretical field capacity (ha/h) } & Treatment (Crop type) & 0.000 & 2 & 0.000 & 12.406 & 0.007 \\
\hline & Error & 0.000 & 6 & 0.000 & & \\
\hline & Total & 0.000 & 8 & & & \\
\hline \multirow{3}{*}{ Field efficiency (\%) } & Treatment (Crop type) & 0.223 & 2 & 0.112 & 1.057 & 0.404 \\
\hline & Error & 0.633 & 6 & 0.106 & & \\
\hline & Total & 0.856 & 8 & & & \\
\hline
\end{tabular}

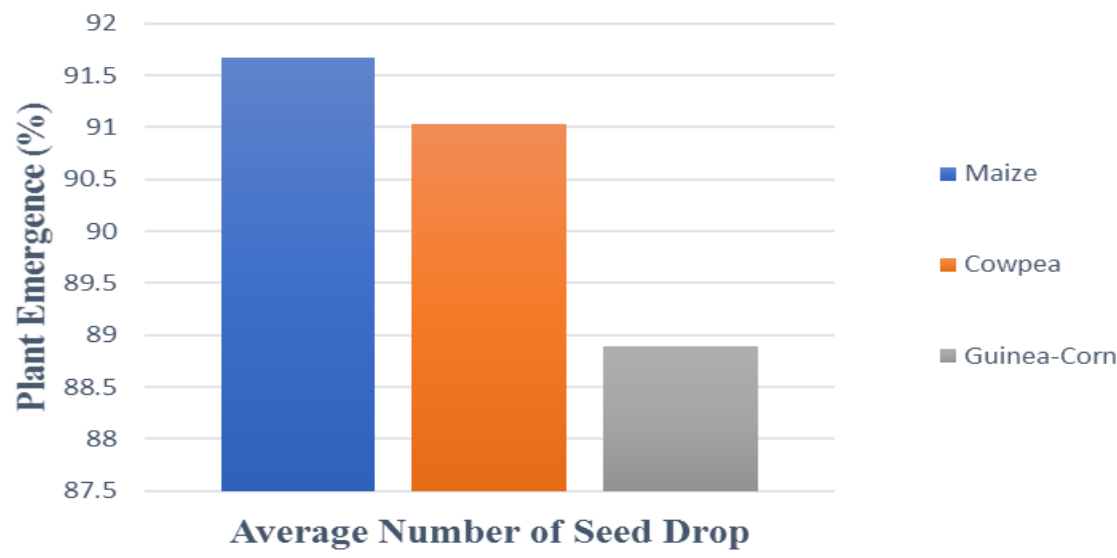

Figure 1. Plant emergence and the average number of seeds drop.

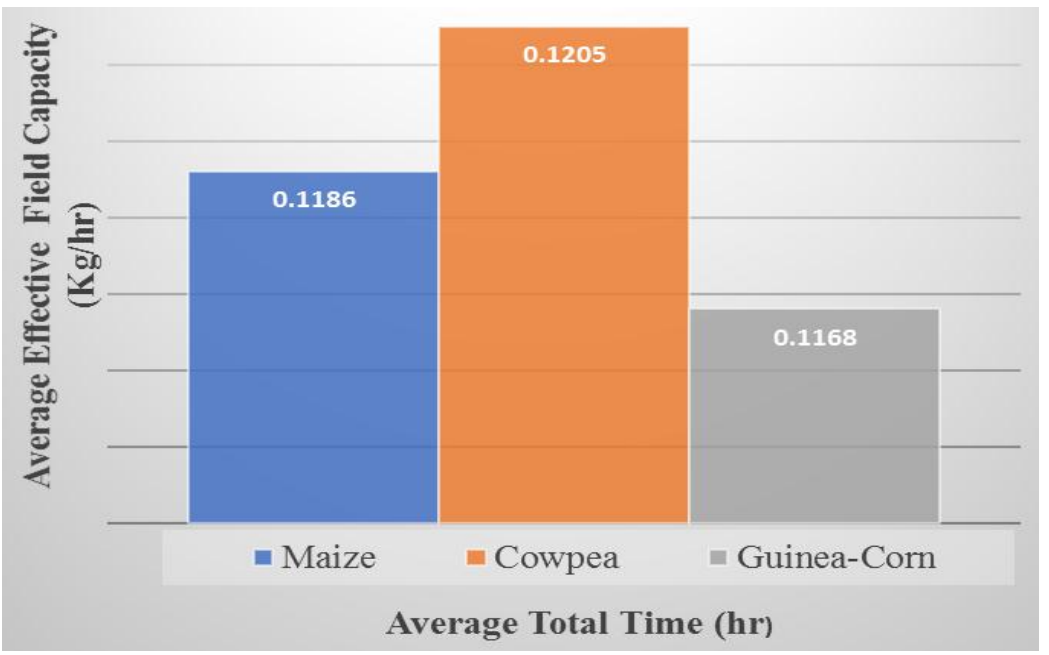

Figure 2. Average effective field capacity vs. average time taking. 
difference in effective field capacity and theoretical field capacity for maize, cowpea and guinea-corn but there was no significant different in field efficiency of the machine for the three crops. Figure 2 also showed that the timeliness of operation will be achieved with this simple seed planter. The need of small and medium Farm holders in Nigeria is fulfilled with the development of manual seed planter which reduces the challenges associated with the traditional method of planting using peasant tools and enhanced planting seed crops to increase food security in Nigeria. The planter is available and affordable for the Nigeria farmers.

\section{REFERENCES}

Adisa AF (2011). Design and Construction of Manually Operated Flute Planter with Fertilizer Distributor. J. Nat. Sci. Eng. Technol. 10(1):178-183.

Alba - Hurst Farms (2004). Effect of Planter Speed on Grain Sorghum Yield, Irwin Porter Quinter, KS.

Conley SP, Stevens WG, Dunn DD (2005). Grain Sorghum Response to Row Spacing, Planting Density and Planter Skips. Crop Management Network, USA.

Ibukun BI, Agidi G, Ikechukwu CU (2014). Design and Fabrication of a Single Row Maize Planter for Garden Use. J. Adv. Eng. Technol. 1:1-6.

Kepner BA, Bainer R, Barger EJ (2005). Principle of Farm Machinery, The AVI Publishing Company, Inc. West port Connecticut.
Kyada AR, Patel DB (2014). Design and Development of Manually Operated Seed Planter Machine. 5th International \& 26th All India Manufacturing Technology, Design and Research Conference (AIMTDR). IIT Guwahati, Assam, India.

Liu W, Tollenaar M, Stewart G, Deen W (2005). Impact of Planter Type, Planting Speed, and Tillage on Stand Uniformity and Yield of Corn. Agron. J. p. 96.

Mabayoje AL, Verma SR (1994). Performance Evaluation of Hand Operated Seed Planter in light and Medium Soil in Nigeria. Agricultural Mechanization in Asia, Africa and Latin America, 25(2):19-23.

Mohammed SS (2002). Determination of Selected Physical and Mechanical Properties of Maize and Sorghum Grains. Unpublished $B$. Eng. Thesis, Ahmadu Bello University, Zaria, Nigeria.

Mohsenin NN (1970). Physical Properties of Plant and Animal Materials (3rd edition.). Gordon and Breach Sci. Publ. New York. pp. 56-91.

Ndirika VIO, Oyegoke OO (2006). Determination of Selected Physical Properties and their Relationships with Moisture Content for Millet. American Society of Agricultural and Biological Engineers (ASABE) 22 (2) Michigan, USA.

Rabbani MA, Hossain MM, Asha JF, Khan NA (2016). Design and Development of a Low-Cost Planter for Maize Establishment. J. Sci. Technol. Environ. Inform. 4:270-279.

Thorat SV, Madhu LK, Patil GV, Patil RN (2017). Design and Fabrication of Seed Sowing Machine. Int. Res. J. Eng. Technol. (IRJET). 4:704-707.

http://www.sciencewebpublishing.net/jacr 


\section{APPENDIX}

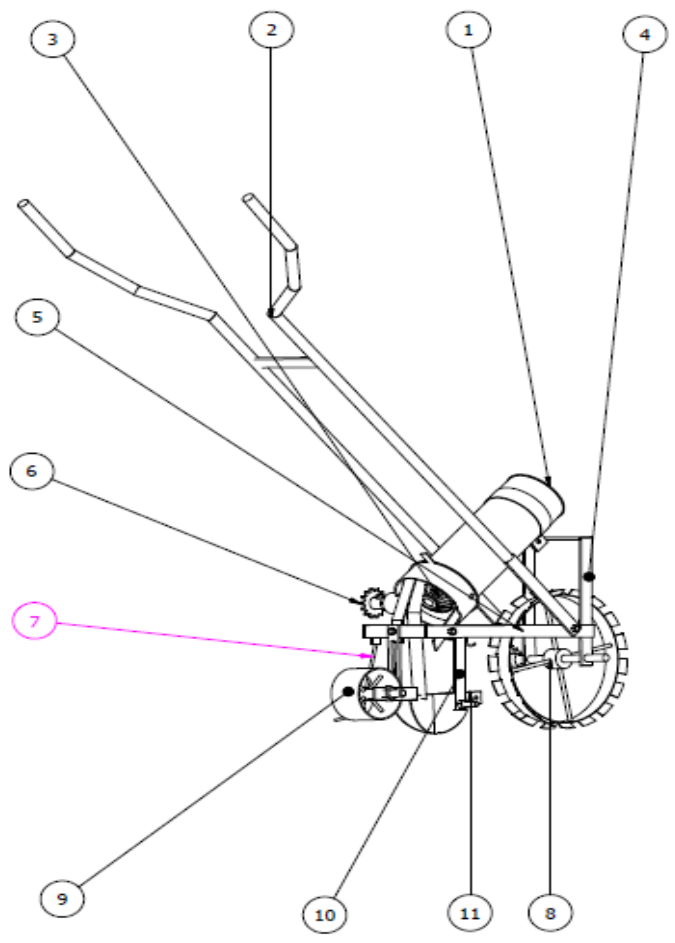

\begin{tabular}{|l|l|}
\hline S/N & Component Name \\
\hline 1 & Hopper \\
2 & Handle \\
3 & Metering Plate \\
4 & Frame \\
5 & Guide \\
6 & Sprocket \\
7 & Chain \\
8 & Ground Wheel \\
9 & Wheel Press \\
10 & Auger \\
11 & Delivery Chute \\
\hline
\end{tabular}

Figure 1. Single row manual seed planter.

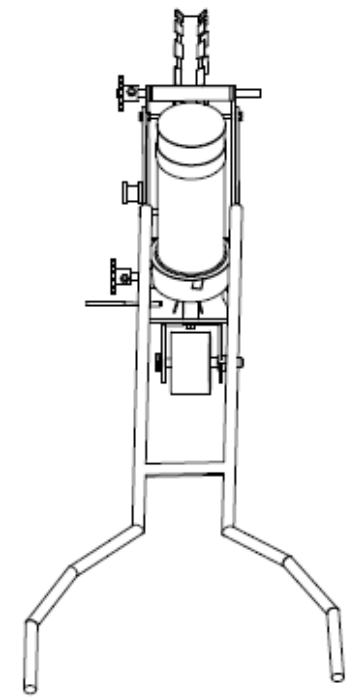

Top View

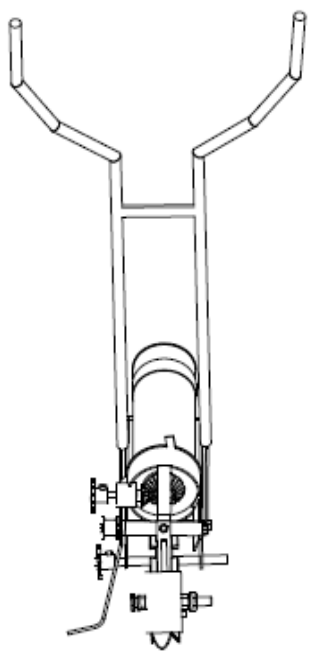

Back View

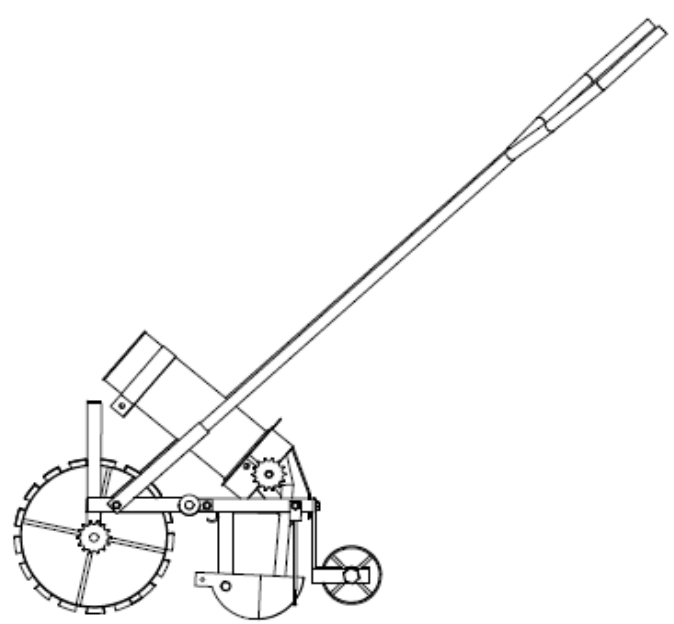

Side View

Figure 2. Different views of the single row manual seed planter. 